\title{
THE EFFORT TO IMPROVE STUDENT MATH CONNECTIONS THROUGH OPEN-ENDED APPROACH IN MATHEMATICS LEARNING IN SMP NEGERI 10 SATU ATAP WONOSOBO
}

\author{
Agus Purwanto ${ }^{\mathrm{a}}$, Sunaryo ${ }^{\mathrm{b}}$ \\ Program Studi Pendidikan Matematika Universitas Ahmad Dahlan \\ Jalan Ring Road Selatan, Tamanan, Banguntapan, Bantul Yogyakarta \\ aadessy8@gmail.com, ${ }^{\mathrm{b}}$ sunaryo.bener@yahoo.com
}

\begin{abstract}
This study was conducted because of the low ability to connect mathematics students in learning mathematics. The purpose of this study is to improve student math connections in the class of VIII SMP Negeri 10 Satu Atap Wonosobo regency in the academic year of 2015/2016 through an open-ended approach. The subjects were a student of class VIII SMP Negeri 10 Satu Atap Wonosobo regency in the academic year of 2015/2016 amounting to 12 students consisting of 5 male students and 7 female students. The object of this research is the process of learning mathematics through the open-ended approach. The study was conducted in three cycles. Data collection techniques used were observation, interview, test, field notes, and triangulation. Data collection instruments such as observation, interviews, test description that has been validated. Data were analyzed using qualitative descriptive analysis. The results showed that the learning of mathematics through an open-ended approach can improve student math connections in a class of VIII SMP Negeri 10 Satu Atap Wonosobo regency in the academic of 2015/2016. This is evident from the results of students' mathematical ability test connection to the percentage indicator of the connection between mathematical topics in the first cycle of $41,67 \%$, the second cycle of $61,11 \%$ and $75 \%$ the third cycle. Percentage indicators mathematical connections with other disciplines in the first cycle of $36,11 \%, 52,78 \%$ for the second cycle and the third cycle of $63,89 \%$. Then the last percentage indicators mathematical connection with the daily life of $52,78 \%$ in the first cycle, the second cycle of $66,67 \%$ and $72,22 \%$ for the third cycle. Increased connections student mathematics good influence on the result of students' mathematics learning.
\end{abstract}

Keywords: Open-ended, Math Connection, Mathematics

\section{INTRODUCTION}

Education in modern times has an important role in the development of a nation. The goal of education is humans, and the purpose of education is to improve the quality of human resources themselves so they can compete in the development of science and technology. One effort to improve the quality of human resources is through the learning process at school. Learning is a stage of change in student behavior that is relatively positive as a result of experience and interaction with the environment that involves cognitive processes. Learning requires the closeness of the material to be learned. The learning process is not just memorizing activities. Studying is not ingesting everything, but to remember what has been taught, students must construct knowledge within themselves. A teacher cannot immediately pour something into the minds of his students, but his students themselves will organize what they hear and see into a meaningful unity. By providing opportunities to discuss, ask questions, submit opinions, practice and even teach friends, a good teaching and learning process will occur.

Many approaches are used in mathematics learning. One approach that can be implemented is open-ended. In the open-ended approach, students are given the freedom to investigate various strategies and ways they believe in solving a problem. Suherman, Erman, et al (2003: 124) suggested that the subject matter of learning with an open-ended approach is learning that builds interactive activities between mathematics and students to invite students to answer problems through various strategies.

Open-ended learning is a learning process in which the goals and desires of individuals/students are built and achieved openly (Hannafin, Hall, Land, \& Hill in the 2013 Miftahul Huda book: 278). Openended learning begins by giving open problems. Open-ended learning activities bring students to answer questions in many ways so that students can improve their intellectual potential and experience in the process of finding something new. Students are given the freedom to connect the knowledge they have 
with the material being studied to solve problems. With an open-ended approach, students' thinking processes in connecting material can be observed. It can be concluded the purpose of the open-ended approach is to develop creative activities and the mathematical mindset of students.

Mathematical connection (mathematical connection) is one of the five standard abilities that students must have in learning mathematics that is applied in The National Counselor of Teacher of Mathematics (NCTM) in Sugiman (2008: 1), namely: problem-solving ability, reasoning ability (reasoning), communication skills (communication), the ability to make connections (connections), and the ability of representation (representation). Mathematical connections can be interpreted as the relationship between mathematical concepts, both between mathematics itself and the relevance of mathematics to other fields of study and everyday life. So that it can be concluded that mathematical connections are a component of the basic abilities that students must possess in learning mathematics which is interpreted as the ability to associate mathematical topics, associate mathematics with other sciences, associate with everyday life.

To improve students' mathematical connections, one of the alternatives chosen was an openended approach. The open-ended approach is thought to be used to improve students' mathematical connection skills. According to Suherman, Erman (2003: 124) in the open-ended approach students are given the freedom to investigate various strategies and ways they believe in solving a problem, bringing students to answer problems in many ways so that students can increase their intellectual potential and experience in the process of finding something new. Students are given the freedom to connect the knowledge they have with the material being studied to solve problems.

Based on the results of interviews with the mathematics teacher of SMP Negeri 10 Satu Atap, Wonosobo Regency, information was found that many found various learning problems, including students, still thought that mathematics was the subject that was considered the most difficult and difficult to understand. Students tend to forget the material that has been taught before. Besides, there were also found several student problems related to solving problems related to the problems of daily life. Students also still have difficulty in connecting objects and mathematical concepts. Students also still have difficulty in determining what formulas will be used to solve questions related to the problems of daily life. Some of the difficulties experienced by students in learning mathematics as mentioned above are problems in learning mathematics, due to a lack of understanding of concepts so that students' mathematical connection skills are low. It can be concluded that the mathematical connection ability of students of class VIII SMP Negeri 10 Satu Atap Wonosobo District is still not optimal. Grade VIII mathematics teachers stated that learning using an open-ended approach had never been done. Learning mathematics leads more to conventional learning.

Based on the description above, the researcher was encouraged to try to do one of the efforts to improve students' mathematical connection skills through teaching mathematics, namely with an openended approach in class VIII SMP Negeri 10 Satu Atap Wonosobo Regency. Based on the background of the problem described above, the problems that exist in the study are defined as follows;

1. Students still think that mathematics is a difficult subject to understand.

2. Students tend to forget the mathematics material that has been taught before.

3. Students still have difficulty in solving questions related to daily life.

4. Students still experience difficulties in connecting concepts and mathematical concepts.

5. SMP Negeri 10 Satu Atap Wonosobo District has never used an open-ended approach in mathematics learning.

Based on the description above, the formulation of the problem in this study is: Does use the open-ended approach improves students' mathematical connections to mathematics learning in class VIII SMP Negeri 10 Satu Atap Wonosobo in Academic Year 2015/2016. While Based on the formulation of the problem, the objectives in this study are: to improve students' mathematical connections through an open-ended approach to learning mathematics in class VIII SMP Negeri 10 Satu Atap Wonosobo in Academic Year 2015/2016. 


\section{METHODS}

1. Type of Research

In this study, the type of research used was Classroom Action Research (CAR). Classroom action research was chosen because of the desire to improve students' mathematical connections through an open-ended approach.

2. Research Design

This study was designed using Classroom Action Research which is divided into several cycles. This research will be carried out during the learning process. According to Arikunto, Suharsimi (2007: 16) in general there are four stages in the cycle of Classroom Action Research, namely planning, implementation, observation, and reflection.

This research was conducted in class VIII SMP Negeri 10 Satu Atap located in Limbangan village, Wadaslintang District, Wonosobo Regency. Class VIII consists of one class. The factors studied are the mathematical connections of students in class VIII SMP Negeri 10 Satu Atap. The study was conducted at the Odd Semester of the 2015/2016 academic year. Implemented by the schedule of mathematics lessons. The study was conducted from January 7, 2016, to January 15, 2016.

This research was conducted in 3 cycles. Each cycle consists of 1 meeting for the cycle I and 2 meetings for cycle II and cycle III. In this study, it was observed that the mathematical connections of students using the open-ended approach. Mathematics learning activities are carried out with a predetermined schedule of 5 hours a week. The time allocation for each lesson is 40 minutes. The study was conducted in 5 meetings.

Table 1. Research Implementation Schedule

\begin{tabular}{|c|c|c|c|}
\hline Stage & Meeting & Date and time & Hour \\
\hline Cycle I & 1 & Thursday, January 7, 2016 & $07.15-08.35$ \\
\hline \multirow{2}{*}{ Cycle II } & 1 & Friday, January 8, 2016 & $07.15-08.35$ \\
\cline { 2 - 4 } & 2 & Saturday, January 9, 2016 & $08.35-09.15$ \\
\hline \multirow{2}{*}{ Cycle III } & 1 & Thursday, January 14, 2016 & $07.15-08.35$ \\
\cline { 2 - 4 } & 2 & Friday, January 15, 2016 & $07.15-08.35$ \\
\hline
\end{tabular}

The subjects of this study were the eighth-grade students of One Roof 10 Middle School in Wonosobo Regency 2015/2016 academic year. While the object in this study is a mathematical connection. The number of class VIII students is 12 students consisting of 5 male students and 7 female students. This research is divided into three cycles, in detail, the steps in each cycle are as follows:

a. Planning

1) Prepare a Learning Implementation Plan (RPP)

2) Arrange observation sheets and interview sheets which are first consulted with the supervisor.

3) Prepare test questions for students, namely tests that will be given at the end of the cycle. Test questions are prepared by the researcher taking into account the teacher concerned.

b. Implementation of actions

The design of the learning process that has been compiled at the planning stage, is implemented at the stage of implementation of the action. At this stage, the researcher acts as a teacher in class VIII and conducts learning through an open-ended approach. Broadly speaking the implementation of actions includes:

1) Initial activity: The teacher gives apperception

2) Core activities:

a) The teacher divides students into several groups

b) The teacher gives a problem

c) Students explore the problem given

d) The teacher records student responses

e) Students write the answers on the board then explain (discussion of student responses)

f) The teacher and students conclude the problem given

3) Final activity: Reflection and Evaluation 
c. Observation

At the observation stage, the researcher observes the students' mathematical connection abilities about the connections between mathematical topics, connections with other sciences, connections with everyday life. This observation is based on the observation sheet that the researcher has made.

d. Reflection

At this stage, the researcher performs data processing, data validation based on the data obtained when at the stage of observation and conducts discussions with partner teachers to consider the good or bad actions taken, and formulate the formulation of planning actions to be taken in the next cycle.

In this study, data collection techniques carried out were observation, interviews, and tests. While the research instrument is a tool used in data collection. The research instruments used included: observation sheets, interview sheets, and description tests. Data analysis conducted in this study is to examine all available data from various sources, namely observation sheets, interviews. The analysis technique that is carried out is:

1. Data reduction is done to select data that is suitable for the research objectives so that the data collected is more focused and more manageable,

2. Presentation of data is done to organize data which is an activity of systematically compiling information from data reduction starting from planning, implementing actions, observing and reflecting to facilitate reading and understanding data,

3. Triangulation of data is interpreted as a technique of collecting data that is related to the various techniques of collecting data and data sources that already exist,

4. Withdrawal of conclusions is the giving of meaning to the data obtained from the presentation of data. Drawing conclusions is based on the results of all data obtained.

The percentage of mathematical connection skills obtained from:

$$
p=\frac{f}{N} \times 100 \%
$$

Information :

$$
\begin{array}{ll}
p & =\text { percentage number } \\
f & =\text { number of scores obtained } \\
N & =\text { ideal score (number of items) }
\end{array}
$$

Table 2. Criteria for Value $P$

\begin{tabular}{|l|c|}
\hline Percentage & Criteria \\
\hline $80 \% \leq \mathrm{P} \leq 100 \%$ & Very high \\
\hline $60 \% \leq \mathrm{P}<80 \%$ & High \\
\hline $40 \% \leq \mathrm{P}<60 \%$ & Medium \\
\hline $20 \% \leq \mathrm{P}<40 \%$ & Low \\
\hline $0 \% \leq \mathrm{P}<20 \%$ & Very low \\
\hline
\end{tabular}

( Riduwan, 2012)

\section{RESULTS AND DISCUSSION}

Research carried out in each cycle includes four components, namely planning, implementing learning, observation, and reflection. The results of class action research in this study are as follows:

Table 3. Percentage of Mathematical Connection Ability of Cycle I Students

\begin{tabular}{|l|l|l|}
\hline No & Indicator & Percentage \\
\hline 1 & Connections between mathematical topics & $41,67 \%$ \\
\hline 2 & Mathematical connections with other sciences & $36,11 \%$ \\
\hline 3 & Connection with everyday life & $52,78 \%$ \\
\hline \multicolumn{2}{|l|}{ Average } & $43,52 \%$ \\
\hline
\end{tabular}

Based on the table above, it is obtained that learning in the first cycle:

a) Students in relating mathematical topics the percentage is $41.67 \%$ so that the criteria are medium. 
b) Students in associating mathematics with other sciences is a percentage of $36.11 \%$ so that it is low in criteria.

c) Students can associate mathematics with daily life with a percentage of $52.78 \%$ so that it is low in criteria.

The average percentage increase in students' mathematical connection ability in cycle I was $43.52 \%$ in low criteria and all indicators of mathematical connections still had not reached the target of success, so corrective action was needed in cycle II. From the results of the math connection test in the first and second meetings of the second cycle can be seen in the following table:

Table 4. Percentage of Mathematical Connection Ability of Students in Cycle II

\begin{tabular}{|l|l|l|}
\hline No & \multicolumn{1}{|c|}{ Indicator } & Percentage \\
\hline 1 & Connections between mathematical topics & $61,11 \%$ \\
\hline 2 & Mathematical connections with other sciences & $52,78 \%$ \\
\hline 3 & Connection with everyday life & $66,67 \%$ \\
\hline Average & $60,18 \%$ \\
\hline
\end{tabular}

Based on the table above, it is obtained that learning in cycle II:

a) Students associate mathematical topics with a percentage of $61.11 \%$ so that they are of high criteria.

b) Students in associating mathematics with other sciences are a percentage of $52.78 \%$ so that the criteria are moderate.

c) Students can associate mathematics with daily life at a percentage of $66.67 \%$ so that it is of high criteria.

The average percentage increase in students' mathematical connection ability in cycle II is $60.18 \%$ so that it has reached high criteria and there is one indicator that has not reached the target of success, namely the indicator of mathematical connection with other sciences, then the research is continued to cycle III. From the results of the mathematical connection test in the first and second meetings of cycle III can be seen in the following table:

Table 5. Percentage of Mathematical Connection Ability of Students in Cycle III

\begin{tabular}{|l|l|c|}
\hline No & \multicolumn{1}{|c|}{ Indicator } & Percentage \\
\hline 1 & Connections between mathematical topics & $75 \%$ \\
\hline 2 & Mathematical connections with other sciences & $63,89 \%$ \\
\hline 3 & Connection with everyday life & $72,22 \%$ \\
\hline Average & $70,37 \%$ \\
\hline
\end{tabular}

Based on the implementation of actions and observations in the first and second meetings of the third cycle in the learning process, all indicators of students' mathematical connection abilities have reached high criteria, so learning mathematics using an open-ended approach was stopped in cycle III.

Based on the research that has been done from the first cycle, cycle II and cycle III concerning learning mathematics through an open-ended approach show an increase in students' mathematical connections. This can be seen from the analysis of the results of the mathematical connection test in the first cycle, second cycle, and the third cycle which has increased. The connection between students' mathematical connections in the first cycle, second cycle, third cycle. 
Table 6. Analysis of the Mathematical Connection Ability of Students in Each Cycle

\begin{tabular}{|c|l|l|l|l|l|}
\hline No & \multicolumn{1}{|c|}{ Indicator } & Cycle I & Cycle II & Cycle III & \multicolumn{1}{|c|}{ Information } \\
\hline 1 & $\begin{array}{l}\text { Connections between mathematical } \\
\text { topics }\end{array}$ & $41,67 \%$ & $61,11 \%$ & $75 \%$ & Increase \\
\hline 2 & $\begin{array}{l}\text { Mathematical connections with other } \\
\text { sciences }\end{array}$ & $36,11 \%$ & $52,78 \%$ & $63,89 \%$ & Increase \\
\hline 3 & Connection with everyday life & $52,78 \%$ & $66,67 \%$ & $72,22 \%$ & Increase \\
\hline \multicolumn{2}{|l|}{ Average } & $43,52 \%$ & $60,18 \%$ & $70,37 \%$ & Increase \\
\hline
\end{tabular}

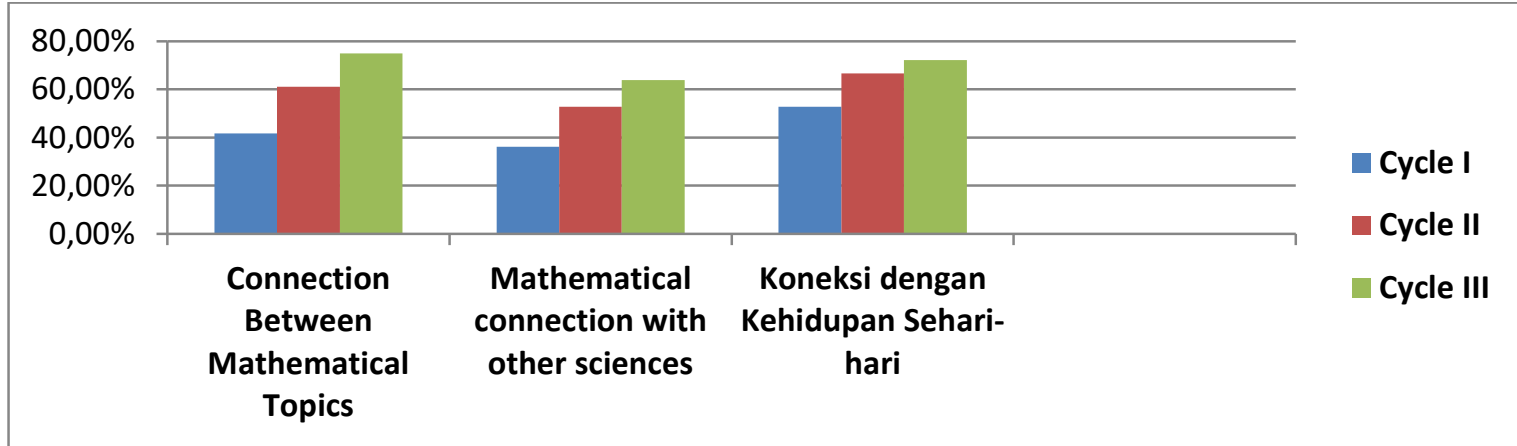

Picture I. Student Mathematics Connection Ability Percentage Chart

Students' responses to mathematics learning using the open-ended approach were very good, as seen from the interviews the following results were obtained:

1. Students and teachers give positive responses to the use of an open-ended approach in mathematics learning.

2. Learning by using an open-ended approach can improve mathematical connection skills in students' mathematics learning.

3. The learning process of mathematics using an open-ended approach goes well and smoothly and provides variations in learning.

The percentage of research success seen from the overall average test results of mathematical connection skills.

Table 7. Percentage of Research Success

\begin{tabular}{|c|c|c|}
\hline Cycle & Percentage & Criteria \\
\hline I & $43,52 \%$ & Medium \\
\hline II & $60,18 \%$ & High \\
\hline III & $70,37 \%$ & High \\
\hline
\end{tabular}

For more details, it will be presented in the following graph:

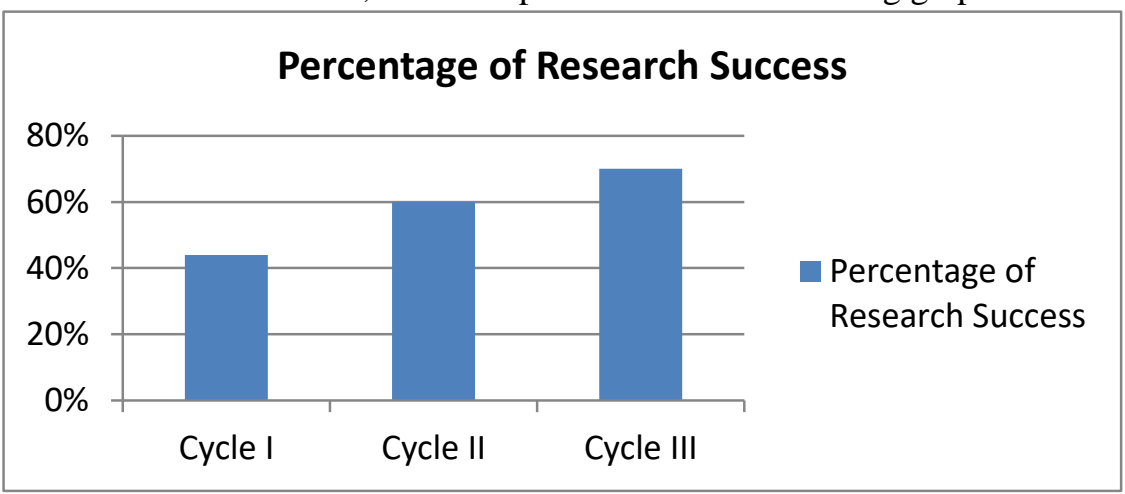

Picture 2. Percentage of Research Succes 
Overall, it can be concluded that mathematics learning through an open-ended approach can improve the mathematical connection of class VIII SMP Negeri 10 Satu Atap Wonosobo District 2015/2016 academic year.

\section{CONCLUSION}

Based on the results of mathematics learning research using an open-ended approach, it can be concluded that it can improve the mathematical connection ability of class VIII C students of SMP Negeri 10 Satu Atap Wonosobo District in the academic year 2015/2016. This can be seen from the following indicators:

1. Based on the results of the math connection ability test, the percentage of indicators linking between mathematical topics in the first cycle was $41.67 \%$, the second cycle was $61.11 \%$ and the third cycle was $75 \%$. Percentage of indicators associates mathematics with other sciences in the first cycle of $36.11 \%$, cycle II is $52.78 \%$ and cycle III is $63.89 \%$. Then the percentage indicator relates to daily life in the first cycle of $52.78 \%$, the second cycle is $66.67 \%$ and the third cycle is $72.22 \%$.

2. Mathematical connections of students using the open-ended approach received a positive response from students based on the results of interviews

\section{REFERENCES}

Arikunto, S. 2012. Penelitian Tindakan Kelas. Jakarta: Bumi Aksara.

Huda, M. 2013. Model-Model Pengajaran dan Pembelajaran:Isu-isu Metodis dan Paragdimatis: Yogyakarta. Pustaka Belajar.

Riduwan. 2012. Dasar-dasar Statistika. Bandung: Alfa Beta.

Sugiman. 2008. "Kemampuan Matematik dalam Pembelajaran Matematika di Sekolah Menengah Pertama". http://staff.uny.ac.id/sites/default/files/131930135/2008_Koneksi_Mat.pdf. Diunduh tanggal: 5 September 2015.

Suherman, E,dkk. 2003. Strategi Pembelajaran Matematika Kontemporer. Bandung: Universitas Pendidikan Indonesia. 